\title{
Development of Transporter for Marine Leisure Ship with Safety and Operation Support System
}

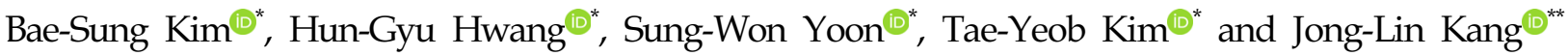 \\ *Ocean ICT \& Advanced Materials Technology Research Division, RIMS, Busan, Korea \\ ${ }^{* * *}$ Human Heary Industries Co. Ltd., Haman, Korea
}

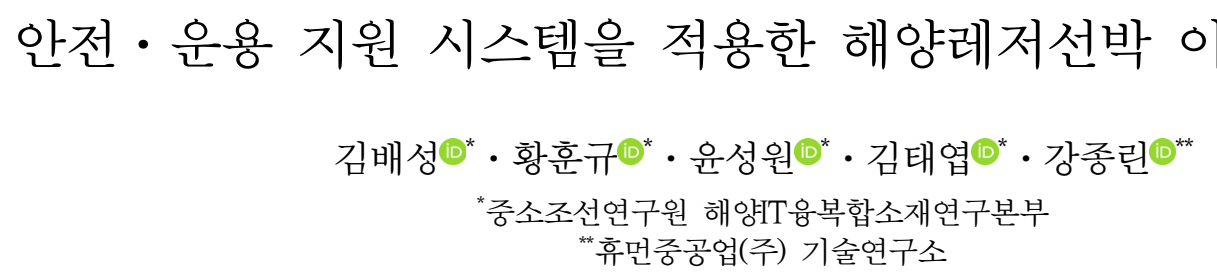

KEY WORDS: Marina 마리나, Marine leisure ship 해양레저선박, Transporter 이송장치, Safety and operation support system 안전 · 운용 지원 시스템, Remote monitoring 원격 모니터링

\begin{abstract}
Recently, the interest in marine leisure activities has been growing rapidly with the work-life balance trend. In response to this demand, the Korean government is supporting fostering and revitalizing the relevant industries and facilities. In particular, a marina has been making efforts to change itself into a resort with multiple amenities instead of a simple mooring facility. However, the facilities in a marina for the transport of marine leisure equipment mostly consist of cranes and boat-lifts using ropes, which can result in incidents such as damage and accidents during lifting or movement. This paper proposes the equipment and support system for the safe transportation of marine leisure ships. Aluminum transport equipment was designed by performing a structural analysis to achieve a lighter weight than the existing steel products. In addition, a safety support system with alarms for tilting or obstacles and a slope monitoring system was developed to enhance the safety during operation and transportation. The safety support system developed in this study was implemented and installed in the transport system, and verified through commissioning on land.
\end{abstract}

\section{1. 서 론}

최근, 사회경제적 수준 향상과 근로시간 단축으로 일과 삶의 균형(워라밸)을 중시하는 소비 흐름에 따라 해양레저활동에 대 한 수요가 급증하고 있으며, 이에 대응하기 위해 정부는 관련 산업 육성과 해양레저장비 활성화를 위한 기반 구축 및 인프라 확충을 지원하고 있다(Kim et al., 2016; Park et al., 2018). 대표 적인 해양레저 공간인 마리나는 관련 예술문화 및 공연 관람, 보트 및 요트의 정박, 수리, 휴식 등 다양한 서비스 시설을 갖추 려는 노력을 하고 있다. 이로 인해 과거 단순하게 선박을 보관 하거나 계류하는 장소라는 인식을 탈피하여 휴양지 개념으로 그 의미가 전환되고 있으며, 지역문화 양성 및 도시와 해양 간 의 교류 촉진 등 연계 산업으로 확장하고 있다(Kim et al., 2018; Park, 2014). 하지만 이러한 노력에도 불구하고 국산 장비에 대 한 불신과 외산 제품에 대한 무조건적인 수용, 특화된 전문 기
술인력 부족 등으로 인하여 국내 기업들이 관련 분야 개발에 적극적으로 뛰어들지 않아 레저활동을 하기 위해 구매되는 대 부분의 장비는 수입에 의존하는 형태가 지속되고 있다(Kim and Hwang, 2018).

한편, 마리나의 출입항 능력을 결정하는 중요한 요소 중 하나 인 상하가 시설은 선박의 계류, 보관, 수리를 목적으로 육해상 을 오가며 양륙 및 이동하기 위한 설비이다. 그 종류는 선양장, 리프트 피어, 포크리프트, 보트리프트, 호이스트 크레인 등이 있 으며, 국내 마리나에 설치 및 운용되는 제품 또한 미국, 유럽, 일본 등에서 제조된 수입제품이 주를 이루고 있다(Moon, 2018). 기존의 상하가 시설을 이용한 레저선박의 운반은 비용과 시간 이 많이 소요되고, 인양 과정에서 와이어 또는 슬링벨트가 사용 되고 있어 풀림이 발생하거나 마모로 인하여 추락사고로 이어 지는 등 작업이 위험하다(Hwang et al., 2017). 또한, 고가인 레 저선박의 특성상 이동과정에서 발생하는 파손 및 결함은 막대

Received 9 August 2019, revised 4 October 2019, accepted 16 October 2019

Corresponding author Hun-Gyu Hwang: +82-51-974-5572, hghwang@rims.re.kr ORCID: http://orcid.org/0000-0001-7119-0719

(c) 2019, The Korean Society of Ocean Engineers

This is an open access article distributed under the terms of the creative commons attribution non-commercial license (http://creativecommons.org/licenses/by-nc/3.0) which permits unrestricted non-commercial use, distribution, and reproduction in any medium, provided the original work is properly cited. 
한 손실로 직결됨으로서 작업자의 전문성과 숙련이 요구된다.

이러한 문제를 해결하기 위하여 본 논문에서는 마리나, 어촌 등에서 15 톤급 이하의 레저선박이나 소형선박을 안전하게 운반 하기 위한 목적의 장치와 연계한 모니터링 및 경보 기능의 시 스템을 제안한다. 이송장치의 설계에 있어 구조물의 특성을 분 석하기 위한 구조해석을 수행하고, 이를 기반으로 제작된 이송 장치와 운반선박 및 운용자의 안전성을 확보를 위한 안전 - 운 용 지원 시스템의 개발에 관한 내용을 다룬다. 본 논문의 2장에 서는 배경 및 필요성을 비롯하여 국내외 관련 제품 동향 및 개 선점에 관해 기술하고, 3 장에서는 장치의 구조해석을 통한 설계 개선 및 검증, 4장에서는 시스템의 설계 및 개발에 관해 서술한 다. 또한, 5 장에서는 이송장치를 제작하여 시스템과 검증하는 내용을 다루며, 6장에서 결론 및 향후 연구로 마무리한다.

\section{2. 해양레저선박 이송장치 관련 동향}

\section{1 국내외 해양레저산업 동향 분석}

세계 각국은 국가적인 차원에서 해양의 가치와 중요성을 제 고하고, 지속가능한 해양 활용 전략을 수립하고 있다. 특히, 현 재 포화 상태인 육상을 대체하기 위한 레저공간으로서의 해양 자원 활용 및 관광산업 육성을 적극적으로 추진하고 있다. 세계 관광기구(UNWTO, United Nations World Tourism Organization) 는 해양레저를 높은 성장 잠재력이 예상되는 분야로 선정하였 으며, 성장가치를 중심으로 투자가 확대되어 향후 전 세계 관광 시장의 50\%를 차지할 것으로 전망하였다(Hong et al., 2015; MOF, 2018).

한국마리나협회 수상레저 통계자료에 따르면 우리나라에 등 록되는 레저선박의 수가 점차적으로 증가하고 있으며, 2017년 3,522 척에 달해 누적된 등록 현황은 24,971척에 이르는 것으로 나타났다. 또한, 조종면허 취득인원도 급증하여 당해 21,596명, 누적 94,794명으로 연간 취득자 2만명 시대가 되었고, 수상레저 사업장 또한 2016년 대비 소폭 증가하여 당해 1,035개소로 조사 되었다(MIAK, 2019). 이러한 추세를 Fig. 1에 도식화하였으며, 이는 해양레저 활동에 대한 국민의 관심이 높아지면서 나타난 흐름의 변화로 분석된다.

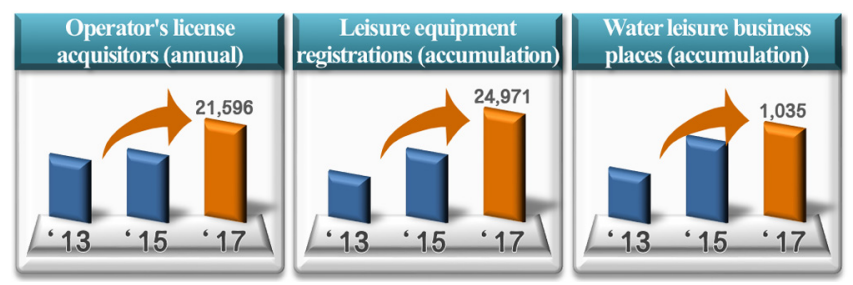

Fig. 1 Status of marine leisure

\section{2 해양레저선박 이송장치 개발 필요성}

현재 마리나에서 선박의 점검, 수리, 보관을 위한 상가 작업 은 선양장, 리프트 피어 등 해수면의 특정 구역으로 선박을 위 치시킨 후에 Fig. 2(a)와 같이 와이어나 슬링벨트를 하부에 감아 연결하고, 고정식 또는 이동식 크레인을 통해 인양하는 방법으 로 진행된다(Marine Travelift, 2019; Stonimage Technology, 2019).
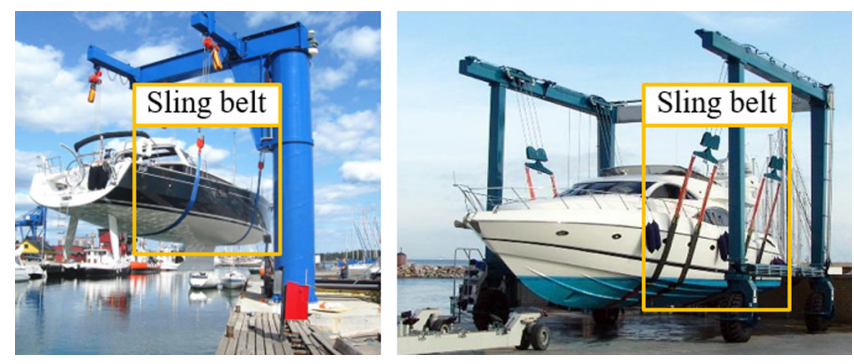

(a) Marina crane and boat-lift
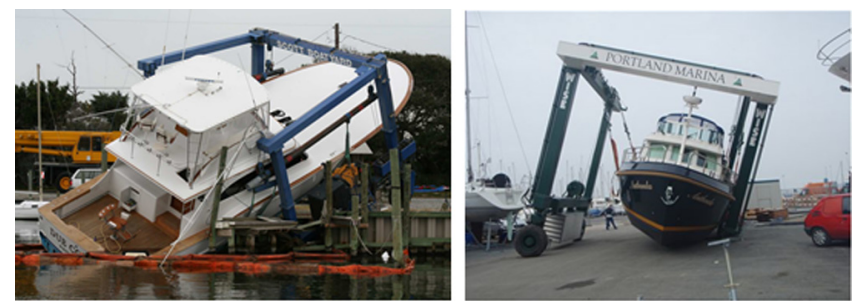

(b) Ship accident cases

Fig. 2 Marina's transporter type and accident cases

이 과정에서 여러 장비와 다수의 지원 인력이 투입되어야 하고, 많은 비용과 시간이 소모된다. 또한, 해당 마리나에서 선박 이 송에 필요한 시설을 보유하고 있지 않거나 운반 대상의 제원에 따라 활용이 불가능한 경우 적합한 장비를 조달하여 사용하여 야 하는 등의 어려움이 있다. 기존의 상하가 시설은 주로 로프 를 연결하여 사용하고 있기 때문에 풀림현상이나 마모로 인해 로프가 끊어져 선박이 추락하거나 운반 과정에서 크레인이 이 송 대상의 무게를 견디지 못하고 전복되는 등 Fig. 2(b)와 같은 사고가 발생될 여지가 있다. 따라서 이러한 문제를 최소화하기 위한 레저선박 이송장치의 개발이 요구된다.

\section{3 해양레저선박 이송장치 차별성 및 개선방안 도출}

본 논문에서는 소형선박과 같은 해양레저선박을 해상에서 육 상으로 상가하거나, 육상에서 해상으로 하가하고, 특정 위치까 지 옮기는 작업을 수행하는 이송장치의 개발에 관한 내용을 다 룬다. 앞서 언급한 각종 문제점을 해결하기 위하여 대상 선박의 하부면에 밀착되어 보다 안정적으로 지지하면서 높낮이와 폭 조절을 통해 선체 형상에 관계없이 인양 및 이송이 가능한 Fig. 3 과 같은 형태의 장비의 개발이 국외에서 선행된바 있다 (Sea-lift, 2019).

현재까지 국내에서는 이와 유사한 형태의 장비가 개발된 사 례가 없기 때문에 마리나 현장청취, 전시회 참관, 제조사 웹사 이트에 게시된 제품 사양 및 홍보자료 등의 매체를 활용한 조
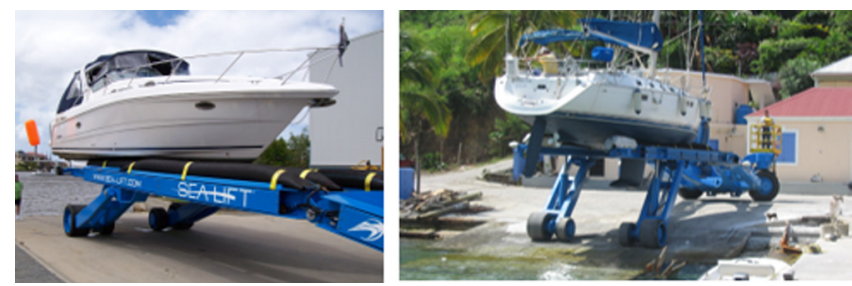

Fig. 3 Developed overseas product 
Table 1 Comparison of specification between existing and proposed systems

\begin{tabular}{ccc}
\hline \hline & Existing system & Proposed system \\
\hline Main material & Steel & Aluminum \\
Lift capacity [ton] & $27 \sim 68$ & 15 \\
Max. ship length [m] & approx. 18-27 & approx. 9 \\
Alarm & - & Gradient alarm and \\
Monitoring & - & rear distance alarm \\
\hline
\end{tabular}

사를 통해 국외에서 개발한 선박 이송장치의 각종 특성을 분석 하였다. 이를 통해 기존 국외 제품과의 차별성과 개선점을 모색 하였다. 그 결과로 Table 1과 같이 해양 환경의 특수성을 고려 한 내구성 개선과 국내 실정을 고려한 성능 목표 설정 및 경량 화가 필요한 것으로 나타났다. 또한, 기존 제품의 경우 운용자 의 경험에 의해 선박 상하가 및 운전을 수행하고 있어 초보자 의 접근이 어렵고, 다양한 위험이 산재되어 있는 마리나 환경에 서 후방에 위치한 장애물 등을 감시하여 불안전한 상황을 전파 하기 위한 조력자가 반드시 동행되어야 되기 때문에 단독 운용 에는 한계가 있다. 따라서 안전성 향상 및 운용 지원을 위한 각 종 센서 등 IT기술을 접목하는 방안이 추가적으로 도출되었다.

먼저, 염분이 많은 운용 환경에서 부식에 대한 내구성 확보 와 경량화를 위해 이송장치의 주요 소재를 강철에서 알루미늄 으로 대체가 가능한지를 검토하였다. 또한, 기존 국외 제품 중 가장 소형 모델의 적재 성능이 약 27 톤으로, 우리나라의 레저선 박 조종면허로 운항이 가능한 선박은 5 톤 미만으로 규정되어 있는 것에 비해 그 성능이 매우 과도하기 때문에 국내에서의 그 활용도를 높일 수 있도록 소형화하고, 운반 대상을 15 톤 이 하의 선박으로 선정하여 설계한다. 한편, 안전성 향상을 위해서 는 기울기 센서, 초음파 거리 센서를 기반으로 양쪽 거치대의 수평이 맞지 않은 상황과 운용 시 주변의 장애물 충돌 위험에 대한 경고를 운용자에게 제공하기 위한 임베디드 시스템을 개 발하여 탑재한다. 아울러, 무선통신을 기반으로 이송장치의 실 시간 운용 상태를 제공하여 원격지에서 작업지원자 및 관리자 의 모니터링이 가능하고 위험 상황 발생시 신속한 대응을 할 수 있도록 지원해주는 소프트웨어를 개발하여 적용한다.

\section{3. 이송장치 설계 및 구조안정성 분석}

\section{1 이송장치 설계}

기존의 국외에서 출시된 제품을 참조하여 SpaceClaim을 기반 으로 해양레저장비 이송장치의 형상을 Fig. 4와 같이 설계하였다 (SpaceClaim Corporation, 2018). 설계한 이송장치는 크게 Front structure, After structure 그리고 Mid structure의 3개 파트로 이루 어지며, 각 부분은 힌지로 연결된다. 먼저, Front structure 파트는 유압을 포함한 구동, 조향, 조정, 주행 모터 등을 제어하는 운용 제어반과 엔진, 펌프, 주행용 전륜용 바퀴, 조향 실린더, 운전석 이 탑재된다. 또한, After structure 파트는 해양레저장비를 운반하 기 위한 선박의 거치대와 상승 및 하강 조절을 위한 유압실린더, 거치대 폭 조절용 유압 실린더, 후륜용 바퀴가 탑재된다. 마지막

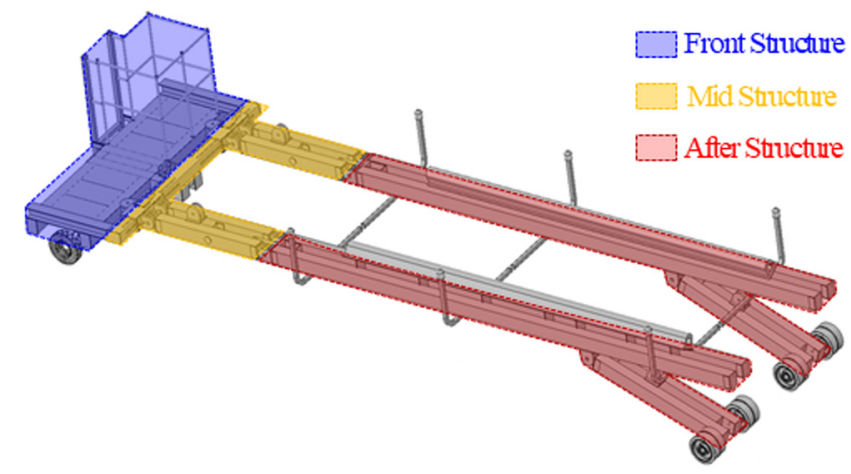

Fig. 4 Design of the transporter

Table 2 Mechanical properties of two main materials

\begin{tabular}{cccccc}
\hline \hline Type & $\begin{array}{c}\text { Yield } \\
\text { strength } \\
{[\mathrm{MPa}]}\end{array}$ & $\begin{array}{c}\text { Tensile } \\
\text { strength } \\
{[\mathrm{MPa}]}\end{array}$ & $\begin{array}{c}\text { Elastic } \\
\text { modulus } \\
{[\mathrm{MPa}]}\end{array}$ & $\begin{array}{c}\text { Poissons } \\
\text { ratio }\end{array}$ & $\begin{array}{c}\text { Density } \\
{\left[\mathrm{kg} / \mathrm{m}^{3}\right]}\end{array}$ \\
\hline Al6082-T6 & 270 & 330 & 72 & 0.33 & 2,700 \\
Al5083-H321 & 215 & 317 & 70.1 & 0.33 & 2,650 \\
\hline
\end{tabular}

으로 Mid structure 파트는 앞서 설명한 두 개의 파트를 연결하고, 거치대 전방부의 상승 및 하강 조절을 위한 유압실린더와 운전 석의 기울기 조절을 위한 작동실린더가 탑재된다.

이송장치의 구조물은 운용환경 및 경량화를 위하여 알루미늄 합금 6082-T6를 적용하였고, 충분한 강성의 유지를 위하여 사각 바 형태의 튜브를 사용하였으며, 판재는 일반적으로 선체 구조 용으로 사용되는 5083-H321 강재를 적용하였다. 특히, 이송장치 의 주재료로 선정된 6082 계열은 해수에 대한 내식성과 우수한 강도를 가지고 있어 선박 및 해양플랜트의 헬리데크, 갱웨이, 구조물, 플랫폼, 사다리 등에 사용되고 있다. 이는 항복강도 $270 \mathrm{MPa}$, 인장강도 $330 \mathrm{MPa}$, 탄성계수 $72 \mathrm{GPa}$, 포아송비 0.3 , 밀도 $2,700 \mathrm{~kg} / \mathrm{m}^{3}$ 의 물성을 가지며, Table 2에 재료의 기계적 성질을 나타내었다(Baek, 2011).

\section{2 구조해석}

해양레저장비 이송장치는 일반적으로 10 톤급이 운송되나, 최 대 설계하중 상태에서의 구조적 안정성을 확인하고자 설계 모 델의 메인 거치대에 Fig. 5와 같이 15톤이 작용하는 상황으로 가정하여 ANSYS mechanical을 통해 구조해석을 수행하였다 (ANSYS., 2018). 이송장치의 실제구조와 같은 거동을 나타내기 위하여 각 파트별 접합부 및 구동 휠 연결부 등에서의 접합 조 건 및 마찰 조건 등의 접촉(Contact) 조건을 설정하였으며, 이송 장치가 정지되어 있는 상태로 가정하여 Front structure 파트와 구동 휠 파트는 고정 경계조건을 적용하였다. 이송장치 모델의 요소망은 해석결과의 정확도와 해석시간의 경제성을 고려하여

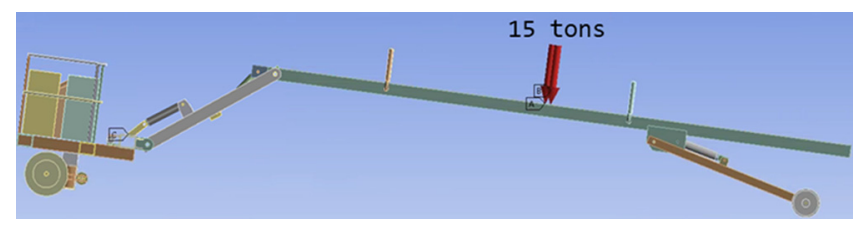

Fig. 5 Loading condition 


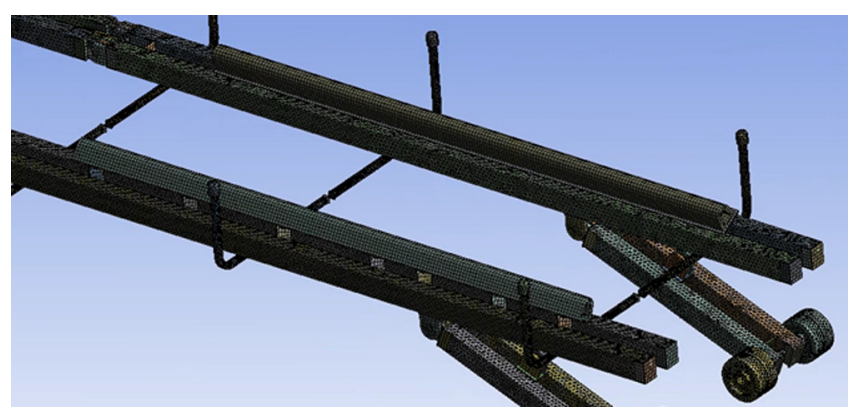

Fig. 6 Finite element mesh of transporter

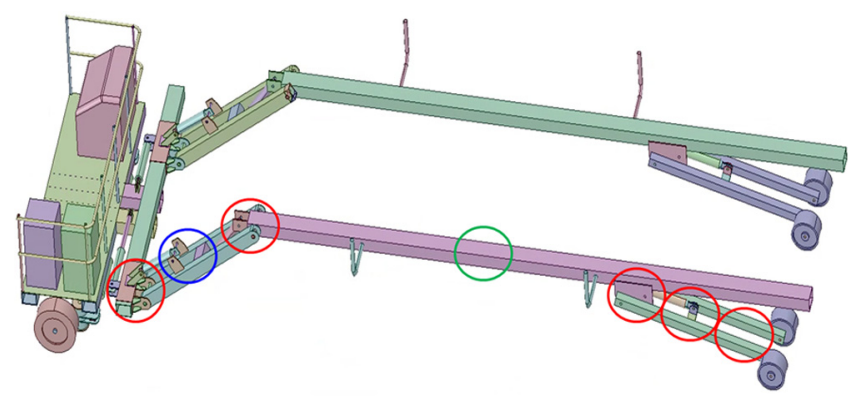

Fig. 7 Initial concept design model and structural weak area

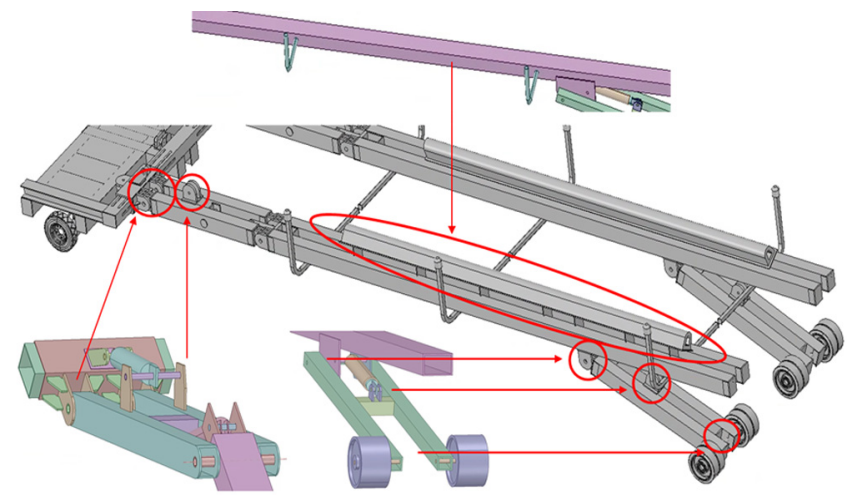

Fig. 8 Secondary reinforcement model of transporter

Fig. 6과 같이 적절한 조밀도를 갖는 요소망을 고려하였으며, 요 소분할을 통해 3,459 개의 요소(Element)와 15,055 개의 절점(Node) 이 사용되었다.

Fig. 7은 초기 개념설계 모델과 구조적 취약부를 나타내었으 며, 초기 모델에 대한 해석결과 유압장비와 연결되는 힌지부에 서 높은 하중이 전달되어 $366.09 \mathrm{MPa}$ 의 응력이 발생하였으며 힌 지부의 두께 증가가 요구되었다. 또한 좌/우 각각 1 기씩 배치된 소형선박이 거치되는 메인 프레임에서 $36.447 \mathrm{~mm}$ 의 처짐이 발 생하여 장기 운용 측면에서 건전성 확보가 어렵다고 판단되어 좌/우 각각 2기의 프레임으로 구성하여 하중을 분산시킴으로서 구조적 안정성을 향상시켰다. 따라서 구조적 안전성을 확보하 고자 Fig. 8 과 같이 1차로 도출된 이송장치의 구조 취약부를 보 강하였다. 개념설계 초안을 유지하며, 두께가 얇아 발생한 취약 부에 한해 각 파트별 약 1.2 1.5배 두께를 증가시키고 형상 변 경이 필요한 부분은 추가 구조보강을 실시하였다.

Fig. 9는 2차 보강된 모델에 대한 해석결과이며, 선박의 충격 으로부터 이송장치 구조물 및 선박의 파손을 막는 고무 방현재

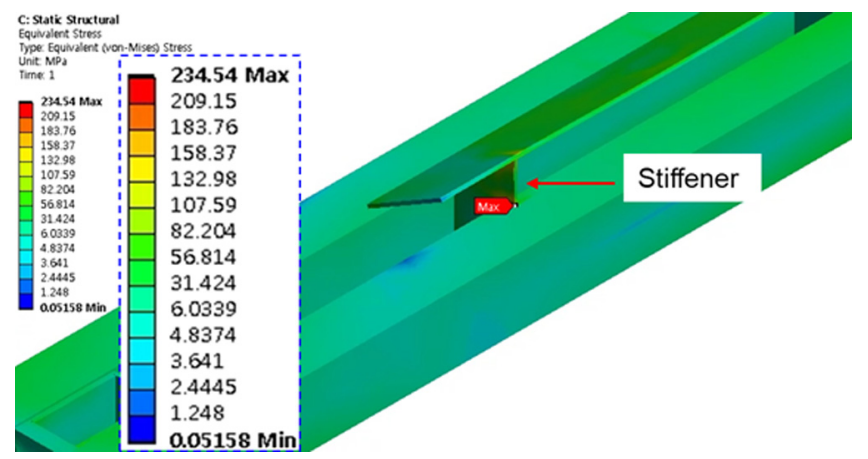

Fig. 9 Finite element analysis result of transporter with stiffener

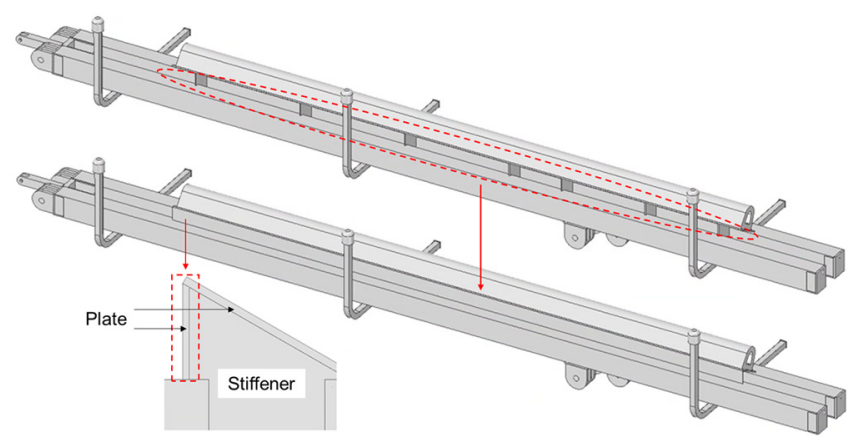

Fig. 10 Final reinforcement model with stiffeners and plates

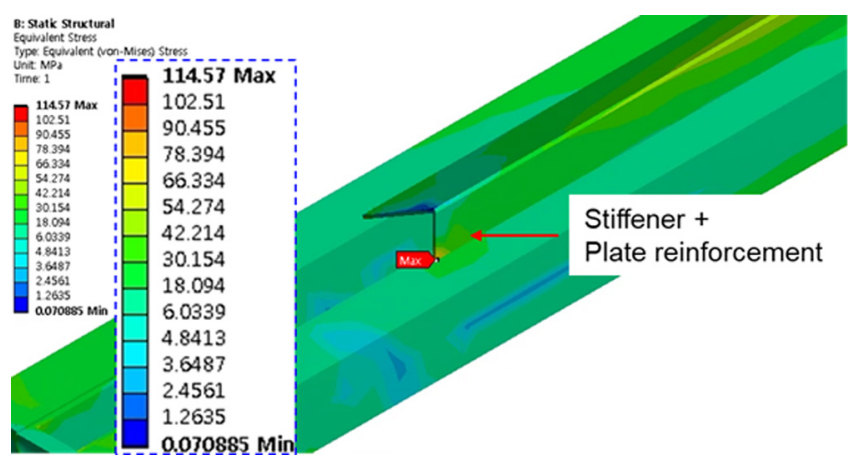

Fig. 11 Finite element analysis result of transporter reinforced with stiffener and plate

(Rubber fender)를 제거하고 해석을 수행하였다. 해석결과 2기 프레임 사이에 위치하여 선박을 거치하기 위한 판재(Plate)를 보 강하는 보강재(Stiffener)에서 $234.54 \mathrm{MPa}$ 로 최대 응력이 발생하 였으며, 구조적으로 보강이 되었으나 응력이 보강재의 특정영 역에 집중되고 있는 것으로 분석되었다. 이를 통해 최대 응력 발생하는 위치가 안전하지 않다 판단되어 Fig. 10과 같이 보강 재 끝단에 응력이 집중되는 것을 막아주기 위해 판재를 사용하 여 구조를 보강하였다.

Fig. 11은 최종적으로 보강된 설계 모델에 대한 해석결과로 서, 이송장치의 장기적인 운용을 위해 응력이 집중되는 지점에 추가 보강을 진행하여 Fig. 9에서 234.54MPa로 집중되는 응력을 114.57MPa로 최대응력분포가 충분히 낮아진 결과를 얻을 수 있 었다. 수치해석을 통해 이송장치 모델에 대한 보강효과를 검증 하였으며, 이를 통해 구조적 안정성을 충분히 확보한 설계 결과 임을 확인하였다. 

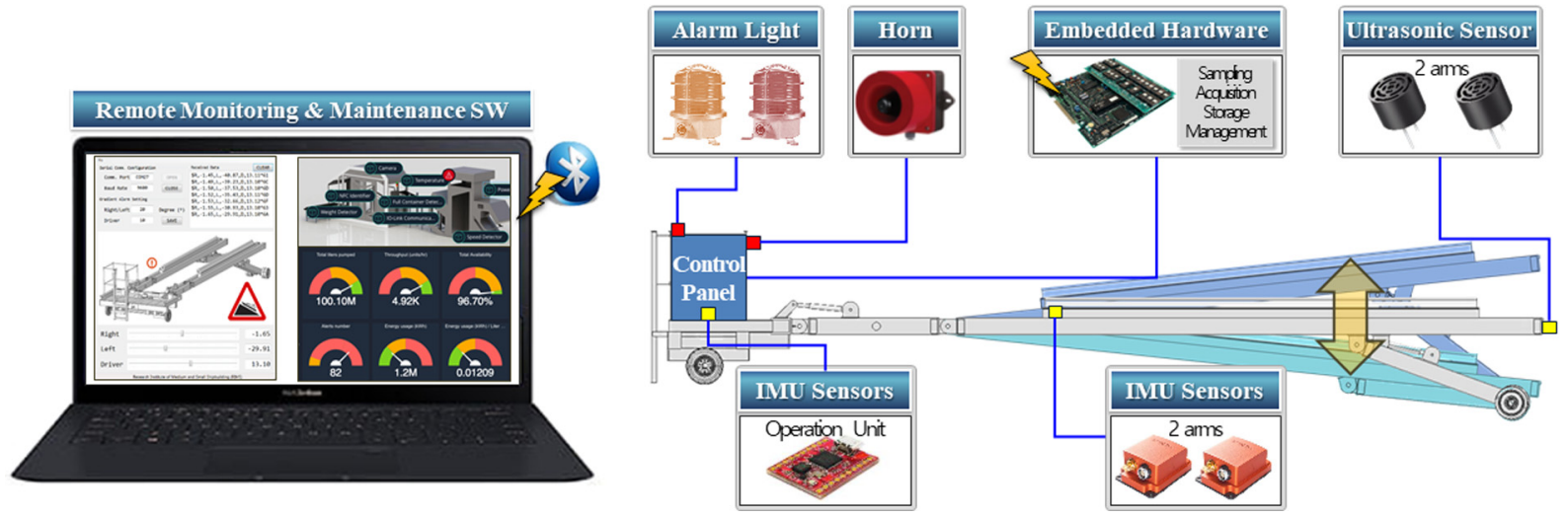

Fig. 12 Arrangement of the safety support system

\section{4. 안전 · 운용 지원 시스템}

해양레저선박 이송장치의 안전 - 운용 지원 시스템은 크게 하 드웨어와 소프트웨어로 구성되며, 주요 구성요소는 Fig. 12와 같이 배치된다.

\section{1 하드웨어 설계 및 제작}

안전 - 운용 지원 시스템 하드웨어는 전방의 거리계측을 위한 초음파 센서, 좌/우 거치대와 운전석의 기울기 계측을 위한 센 서, 센서 계측데이터 수집부, 기울기 계측값을 유압제어반으로 전달하기 위한 통신 인터페이스부, 경고 발생장치의 제어와 시 스템을 전반적으로 관리하는 제어관리부, 모니터링 소프트웨어 로 실시간 계측값을 송신 및 경고용 기울기 설정값을 수신하기 위한 블루투스 모듈로 구성되며, 이를 Fig. 13에 도시하였다. 운 반 과정에서 전방의 장애물 충돌 예방과 거치된 선박의 낙하 방지 및 상태 인지를 위한 운용자의 경계 지원용 경고 발생을 위하여 경고등, 전자혼을 배치하였다. 경고등의 경우 이송장치 운용 시 연속적으로 동작하는 황색등과 이상 상황에서만 켜지 는 적색등으로 2식을 탑재하였다. 기울기 계측은 가속도와 자이 로 기능이 융합된 센서를 활용하였으며, 이송장치가 선박을 상 하가하는 과정에서 거치대가 수중에 잠기는 등 운용 특성을 고 려하여 거치대용 기울기 센서와 초음파 센서는 방수형으로 채 택하였다.

본 논문에서 다루는 안전 - 운용 지원 시스템의 하드웨어에 대한 회로 및 $\mathrm{PCB}$ (Printed-circuit board)를 설계하기 위한 도구는 Altium designer 16을 활용하였고, 개발 도구는 Atmel studio 7, 개발 언어는 $\mathrm{C}$ 언어를 사용하였다. 시스템의 각 구성체계의 연

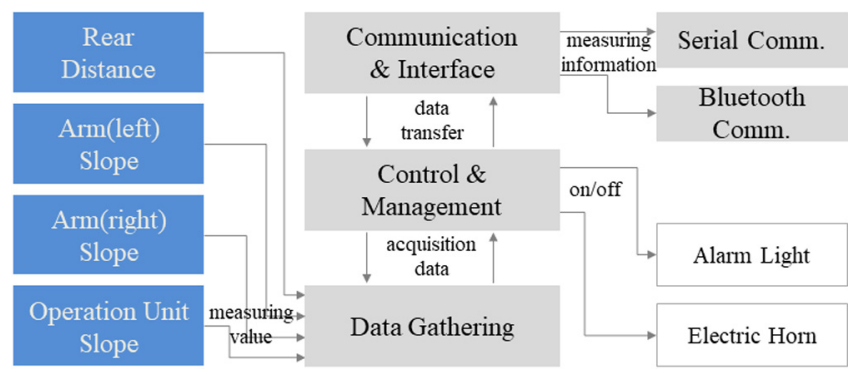

Fig. 13 Diagram of the system hardware

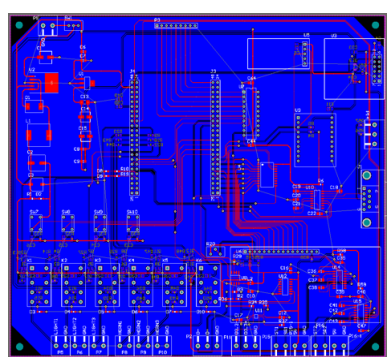

(a) Designed PCB

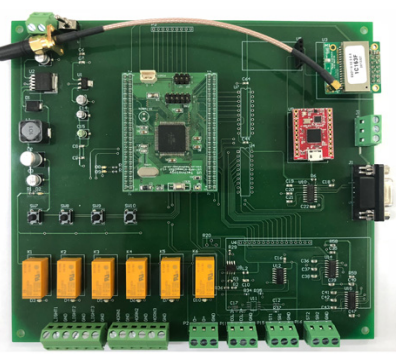

(b) Implemented board
Fig. 14 Designed and implemented board

동 및 기능 제어를 위해 Atmel 사의 ATmega 2560 마이크로프로 세서를 사용하였고, 거리계측용 초음파 센서는 Elecrow 사의 JSN-B02, 좌/우 거치대용 기울기 센서는 Xsense 사의 MTi-20 VRU, 운전석용 기울기 센서는 Withrobot 사의 myAHRS+, 블루 투스 통신모듈은 외부 스터브 안테나와 케이블이 연결된 Chipsen 사의 Parani-ESD110B-DU를 사용하였다. 또한 경고등은 Qlight 사의 SH1LRP-A(황색)과 SH1LRP-R(적색), 전자혼은 동일 한 제조사의 QWH50을 각각 사용하여 시스템을 구성하였다.

설계 내용을 기반으로 Fig. 14와 같이 해양레저선박 이송장치 의 안전 - 운용 지원 시스템을 구성하는 보드를 제작하였다. 마 이크로프로세서와 운전석 기울기 센서 및 무선통신모듈은 온보 드에 탑재하였고, 외부에 설치되는 거치대 기울기 센서 및 초음 파 센서, 경고 발생장치와의 인터페이스는 작업자의 편의성을 고려하여 커넥터를 통해 연결되도록 배치하였다.

\section{2 원격 기울기 모니터링 소프트웨어}

기울기 센서로부터 계측한 데이터를 블루투스 기반 무선통신 모듈과 연동하여 PC 기반으로 원격 기울기 모니터링 및 경보 기능을 제공하는 소프트웨어를 개발하였다. 기본적으로 해양레 저선박 이송장치에 탑재된 하드웨어를 통해 위험에 대한 경고 를 물리적(광원, 소리)으로 제공한다. 추가적으로 무선 블루투스 통신 기반 원격 기울기 모니터링 소프트웨어를 통해 각 상황에 따른 정보를 시각적으로 표현하여 작업지원자 및 관리자 등이 직접 현장에 위치하지 않아도 운용 시 발생할 수 있는 문제를 인지함으로서 즉각적인 의사결정과 필요한 조치를 지원하는 등 병행적 안전 향상 수단으로 활용이 가능하다. 원격 기울기 모니 터링 소프트웨어의 주요기능을 Table 3 과 같이 정의하였다. 
Table 3 Function of the software

\begin{tabular}{|c|c|}
\hline Function & Description \\
\hline $\begin{array}{l}\text { Bluetooth } \\
\text { communication }\end{array}$ & $\begin{array}{c}\text { Communications connectivity and } \\
\text { disconnection }\end{array}$ \\
\hline $\begin{array}{l}\text { Serial comm. } \\
\text { setting }\end{array}$ & COM port and baud rate setting \\
\hline Receive data display & $\begin{array}{l}\text { Real-time display of data received } \\
\text { from embedded system }\end{array}$ \\
\hline $\begin{array}{l}\text { Receive data } \\
\text { processing }\end{array}$ & $\begin{array}{l}\text { Processing data received from embedded } \\
\text { system }\end{array}$ \\
\hline $\begin{array}{l}\text { Slope data } \\
\text { display }\end{array}$ & Text box and track bar \\
\hline $\begin{array}{l}\text { Slope alarm } \\
\text { visualization }\end{array}$ & Image-based slope alarm position \\
\hline $\begin{array}{l}\text { Sensor abnormal } \\
\text { state alarm }\end{array}$ & $\begin{array}{c}\text { Display of non-receiving alarm } \\
\text { by sensor }\end{array}$ \\
\hline $\begin{array}{l}\text { Alarm slope value } \\
\text { setting }\end{array}$ & $\begin{array}{l}\text { Set Left/Right cradle and driving } \\
\text { alarm reference value }\end{array}$ \\
\hline
\end{tabular}

Table 4 HW-SW data exchange protocol

\begin{tabular}{|c|c|c|}
\hline & \multicolumn{2}{|c|}{ \$R,xxx.xx,L,xxx.xx,D,xxx.xx*hh $<\mathrm{CR}><\mathrm{LF}>$} \\
\hline & $\rightarrow 1 \quad \bigsqcup_{2} \quad \bigsqcup_{3}$ & \\
\hline Field 1 & Slope of right arm & $-180.00 \sim 180.00$ \\
\hline Field 2 & Slope of left arm & $-180.00 \sim 180.00$ \\
\hline Field 3 & Slope of operation unit & $-180.00 \sim 180.00$ \\
\hline
\end{tabular}

해양레저선박 이송장치의 좌/우 거치대, 운전석에 기울기 계 측을 위한 센서를 통해 수집되는 데이터를 소프트웨어와 상호 교환하기 위한 프로토콜의 정의가 요구된다. 좌/우 거치대부에 설치되는 센서는 16 진수 $\mathrm{Hex}$ 값으로 데이터를 발생하며, 운전 석에 탑재되는 센서는 ACSII 값으로 계측 값을 발생하기 때문 에 이를 통일하기 위해 선박의 디지털 인터페이스 표준인 NMEA 0183(IEC 61162-1/2 표준) 형식을 차용하여 데이터를 상 호 교환하기 위한 프로토콜을 Table 4와 같이 설계하였다.

'\$'으로 데이터의 시작을 알리며, 'R'은 우측 거치대를 의미 하고, 데이터 필드 1 에 우측 해당 센서의 기울기 계측값을 나타 낸다. 다음으로 ' $\mathrm{L}$ '과 ' $\mathrm{D}$ '는 좌측 거치대와 운전석을 의미하며, 데이터 필드 2 와 3 에 각각의 센서 계측값을 나타낸다. 센서 데 이터의 범위는 거치대가 전방으로 기울어진 경우 음수의 값을 가지고, 반대의 상황에서는 양수의 값을 가지도록 설정하였다.

소프트웨어 개발 환경은 Microsoft Windows 10 의 운영체제에 서 Microsoft Visual studio 2015의 개발도구를 사용하여 C++ 및 C\# 언어로 개발하였으며, 하드웨어와 무선 데이터 교환을 위하 여 USB 형태의 안테나 내장형 블루투스 통신모듈인 Parani$\mathrm{ESD} 100 \mathrm{~V} 2$ 를 선정하여 활용하였다. Table 3에서 정의한 주요 기 능들을 사용자에게 직관적이고 효과적으로 표현해주기 위한 그 래픽 사용자 인터페이스(GUI, Graphic user interface)를 Fig. 15와 같이 설계하였다. 이는 (1) 시리얼 포트 설정 및 통신 연결/해제 부, (2) 기울기 경보 기준값 설정부, (3) 실시간 수신데이터 출력 부, (4) 경보 발생 및 위치 시각화부, (5) 기울기 계측값 표시부,
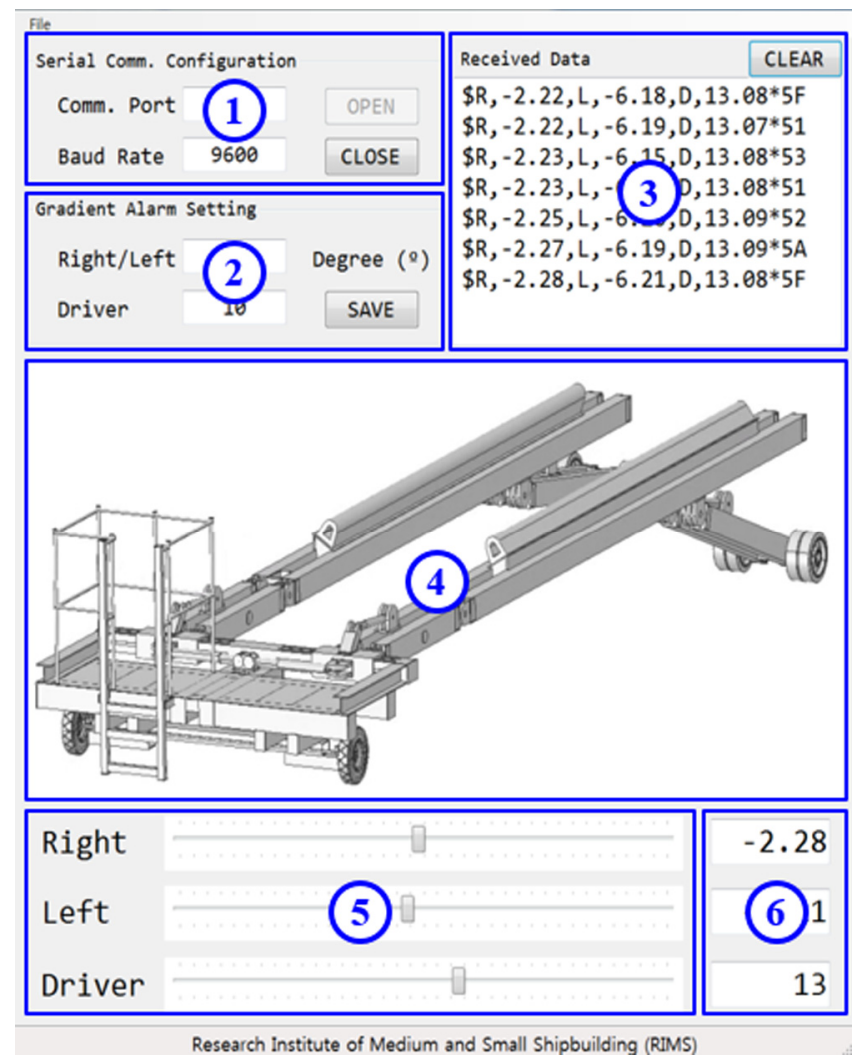

Fig. 15 User interface configuration

(6) 센서 상태 표시부로 구성된다. 특히, 경보 발생 및 위치 시각 화부에서 기울기에 대한 이상 경보 및 발생 위치(우축 거치대 전/후, 좌측 거치대 전/후, 운전석)를 이송장치 이미지 상에 전시 하며, 센서 상태 표시부에서 데이터 수신 여부와 허용된 계측값 을 벗어나는 등의 이상 여부에 따라 정상(흰색), 비정상(적색) 상태가 구분되어 표현되도록 개발하였다.

\section{5. 이송장치 제작 및 테스트}

\section{1 이송장치 제작}

구조해석을 통하여 적합성이 확보된 형상을 기반으로 도면을 작성하였다. Front structure, After structure, Mid structure의 각 연 결부는 힌지로 연결되도록 설계하였고, 용접변형을 고려해 각 각의 프레임을 완전 용접 후 기계가공을 통하여 구현하였다. 메 인 프레임을 구성하는 부분은 사각 튜브를 사용하여 경량화된 6082-T6 알루미늄으로 단면계수를 높게 하였으며, 다양한 두께 의 판재는 선체부분에 사용되는 5083-H321으로 하였다. 구성요 소의 자재들은 두께에 따라 워터젯 절단기와 핸드커팅 장비를 활용하여 절단하였다. 용접 중 발생되는 수축치를 고려하여 마 진을 적용하고, 개선시공을 통하여 용접면의 강도를 유지하도 록 하였다. 알루미늄은 일반 강철에 비해 열팽창계수가 높아 용 접으로 인한 수축량이 크게 발생하기 때문에 Fig. 16과 같이 용 접 후 가스토치로 삼각 가열하여 변형을 최소화하고, 일부 구조 물에 대해서는 변형을 예상하여 Fig. 17과 같이 (a)중량물을 설 치하거나 (b)임시 부착물을 통하여 강제 구속시키는 방법을 적 용하였다. 


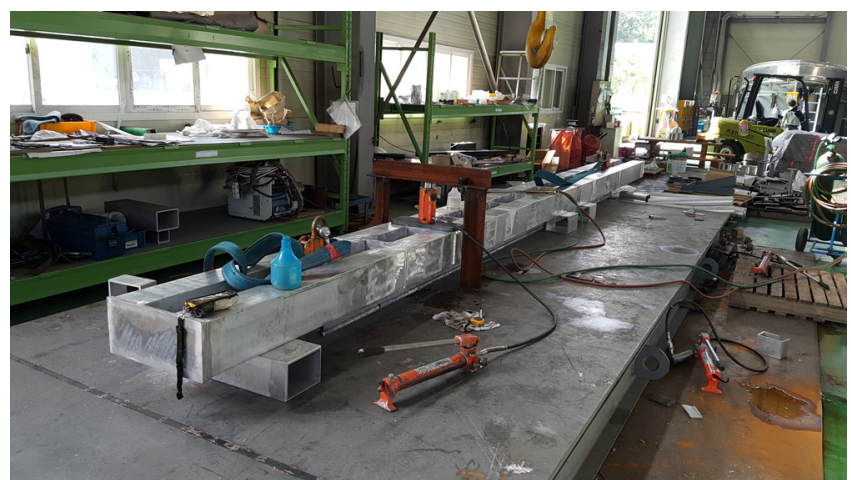

Fig. 16 Method for welding distortion correction

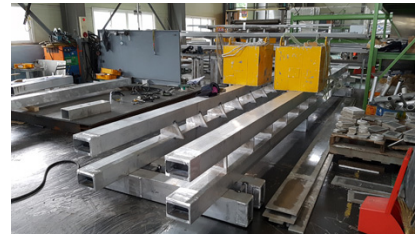

(a) Heavyweight installation

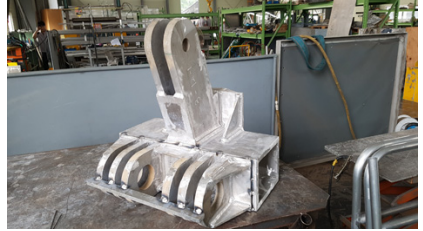

(b) Temporary attachment
Fig. 17 Methods for minimization of welding distortion

가공된 Front structure 파트에 전륜부를 연결하는 구조물을 조립하고, 이송장치가 주행하는 방향을 조종하기 위한 조향 실 린더와 전륜용 바퀴, 운전석을 탑재하였다. After structure 파트 에는 후륜부를 연결하는 구조물을 조립하고, 거치된 선박의 후 방부 상하가를 조절하기 위한 유압 실린더와 후륜용 바퀴를 탑 재하였다. Mid structure 파트에는 거치된 선박의 전방부 상하가 를 조절하기 위한 유압 실린더와 운전석의 기울기 조절을 위한 작동 실린더를 탑재하고, Front structure 파트와 After structure 파트가 연결되도록 결합하였다. 각 파트의 회전 운동 축을 지지 하는 베어링의 경우 해수에 침수되는 조건과 좁은 틈에 설치되

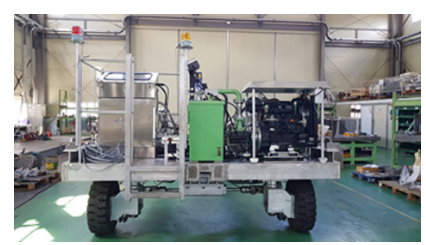

(a) Front view

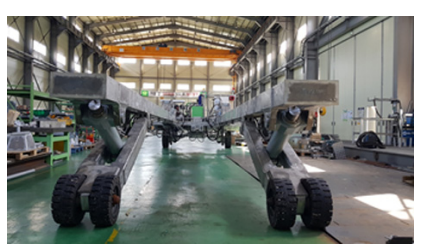

(b) Rear view

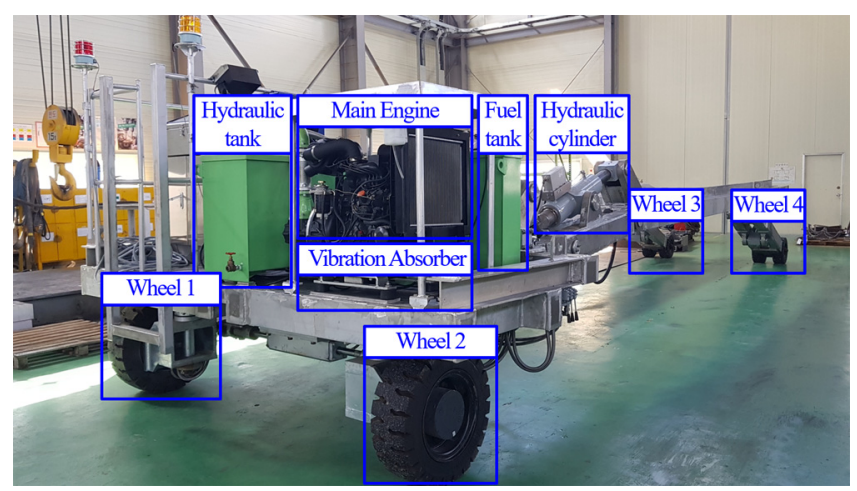

(c) Side view

Fig. 18 Implemented transporter

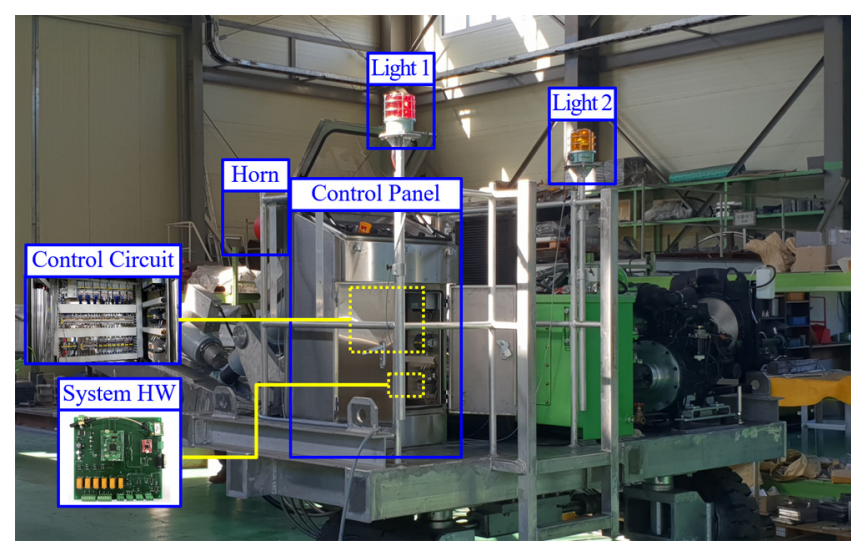

Fig. 19 Implemented operation unit

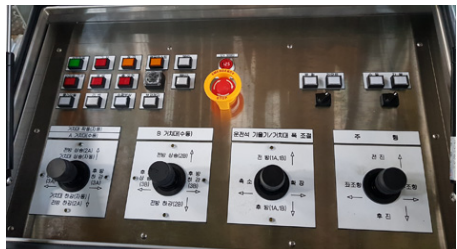

(a) Fixed controller

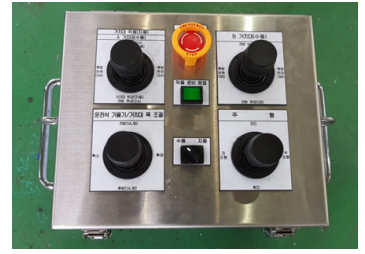

(b) Portable controller
Fig. 20 Implemented controller

는 것을 고려하여 장기간 또는 영구적으로 윤활유를 주입하지 않아도 되는 오일-리스 제품으로 적용하였다. 조립된 구조물에 구동을 위한 엔진과 진동흡수장치, 주행 바퀴, 유압/연료 탱크 등을 설치하여 이송장치를 제작하였고, 이를 Fig. 18에 나타내 었다.

이송장치의 운전석 좌/우, 거치대 전방 좌/우, 거치대 후방 좌 /우, 거치대 폭, 조향, 주행모터 등 9개의 유압 실린더를 동작 및 제어하기 위해 Rexroth 사의 IndraControl XM21을 사용하여 회 로를 개발하였다. 이의 보호를 위해 컨트롤 판넬을 제작하여 안 전 - 운용 지원 시스템의 하드웨어와 함께 설치하였고, 경고등 2 식과 전자혼을 주변에 배치하여 연결하였다. 구성요소가 설치 된 운전석을 Fig. 19에 나타내었다. 또한 이송장치의 조종을 위 해 컨트롤 판넬 상단에 설치되는 고정형 컨트롤러는 Fig. 20의 (a)와 같이 조종스틱 및 버튼으로 구성하여 제작하고, 운전석을 벗어나 근거리에서 주변상황을 파악함과 동시에 이송장치를 제 어할 수 있는 이동형 컨트롤러도 (b)와 같이 개발하였다.

Front structure에 위치한 컨트롤 판넬 내부에 이송장치의 안 전 - 운용 지원 시스템 보드와 운전석 기울기 계측용 센서를 배 치하였으며, 외부에는 경고등과 전자혼을 탑재하였다. 좌/우 거 치대 기울기 계측용 센서는 Mid structure에서 시스템 보드와 가 장 가까운 위치에 이송장치와 동일한 알루미늄 재질의 보호케 이스를 배치하여 그 내부에 고정하였고, 초음파 센서는 후방 장 애물 감지를 위해 After structure의 최외각에 고정하였다.

\section{2 이송장치 테스트}

제작된 이송장치의 구조적인 안전성 및 유용성 검증을 위해 Fig. 21 과 같이 운반 대상인 해양레저선박을 대체하는 15 톤의 중량물을 거치대에 적재하여 구동, 정지, 주행, 조향, 상하가 등 시운전을 수행하였다. 이 과정에서 거치대 프레임, 핀, 바퀴 등 


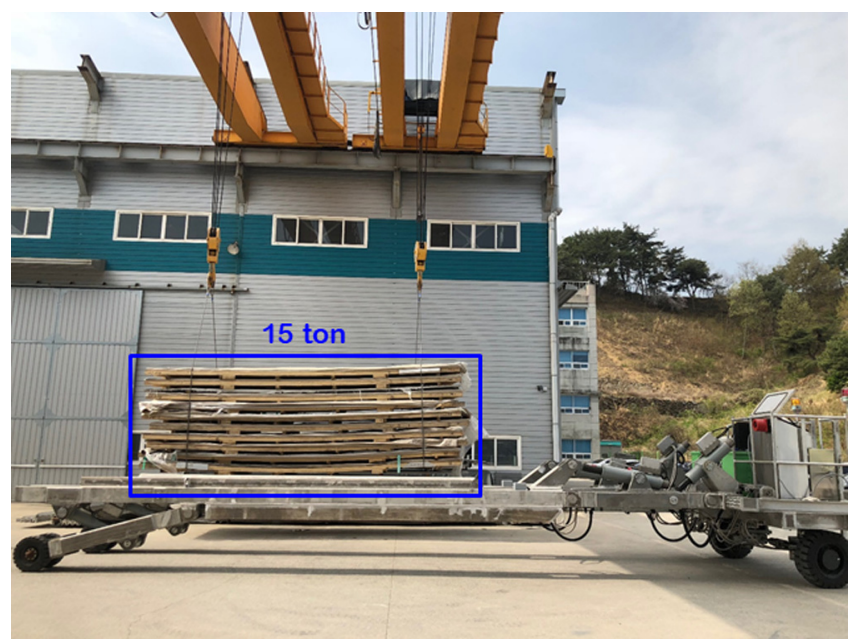

Fig. 21 A test run of the transporter

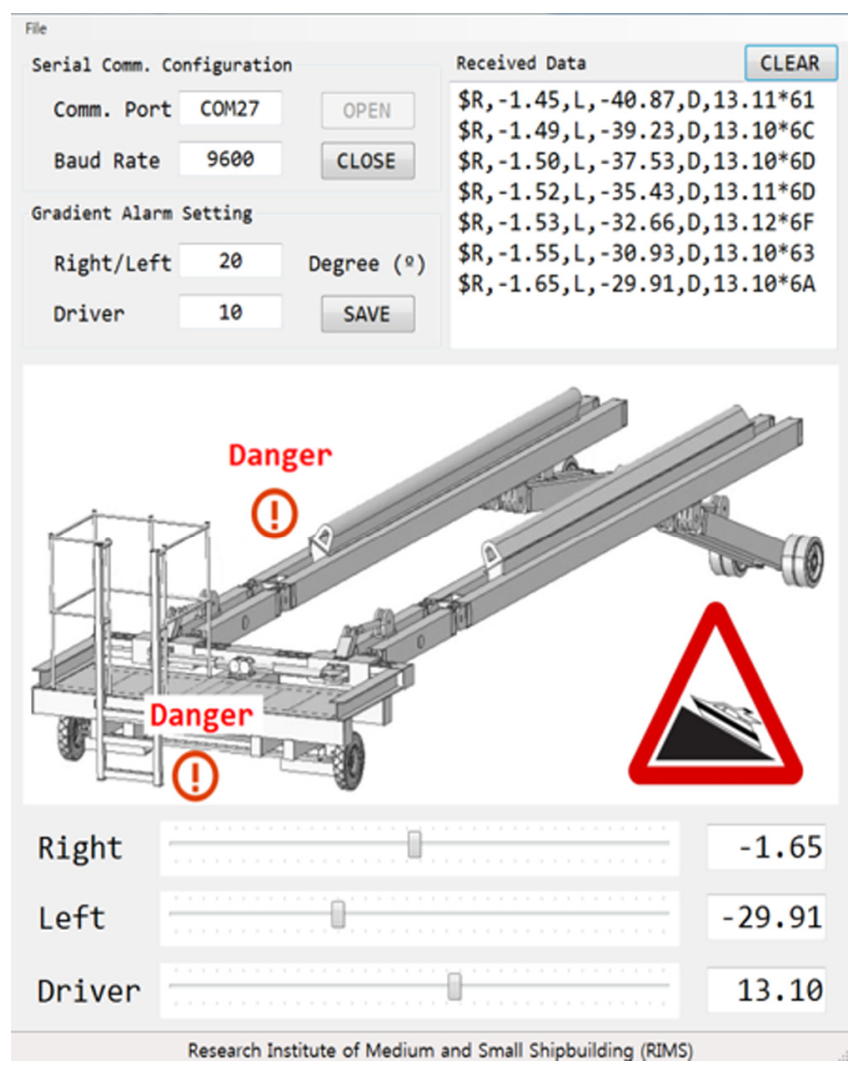

Fig. 22 Display of the software (alarm : left arm, operation unit)

전체적으로 구조물의 변형이 발생하지 않은 것으로 확인되었으 며, 이동속도 $3 \mathrm{~km} / \mathrm{h}$, 등판가능 경사면 10 도, 진동 $6 \mathrm{~mm} / \mathrm{s}$, 소음 $110 \mathrm{~dB}$ 이하의 실측값을 확보하였다.

실제 제작된 이송장치를 기반으로 탑재된 안전 - 운용 지원 시스템 하드웨어와 소프트웨어 간의 연동테스트를 수행하였다. 3 종의 센서 및 하드웨어를 통해 주기적(1초)으로 계측된 기울기 센서 데이터는 블루투스 통신으로 소프트웨어가 설치된 $\mathrm{PC}$ 에 전송되고, 수신된 데이터가 정상적으로 전시되는 것을 확인하 였다. 이송장치의 시운전 과정에서 좌측 거치대와 운전석이 설 정된 기울기 기준값(좌/우 거치대 : 20 도, 운전석 : 10 도) 이상으
로 기울여져 FIg. 22와 같이 출력되어 설계 내용과 부합하는지 를 확인하였다. 하드웨어와 직접 연동되는 경고등, 전자혼의 경 우 기울기 및 초음파 센서의 데이터 계측을 통해 기울기 기준 값 이상 및 접근거리 $(3 \mathrm{~m})$ 이하 상황에 따라 동작하는 것을 확인 하였다.

\section{6. 결 론}

본 논문에서는 마리나에서 해양레저선박의 상하가 및 운반을 안전하게 수행하기 위한 이송장치를 설계하였다. 해양환경에서 운용되는 특성과 구조물의 경량화를 위하여 해수에 대한 내식 성과 우수한 강도를 가지는 알루미늄 합금 Al6082-T6를 주재료 로 하여 구조해석을 수행하였고, 도출된 문제점을 개선한 모델 을 재설계하여 안전성을 검증하였다. 구조적 적합성이 확보된 각각의 구조물을 가공하고, 유압장치 및 주행바퀴와 이를 구동 하는 제어반 등 구성요소를 탑재하여 이송장치를 제작하였다. 또한 고가의 레저선박을 운반하는 과정에서 발생할 수 있는 추 락이나 파손사고를 예방하기 위하여 이송장치의 좌/우 거치대 및 운전석의 기울기 계측과 후방의 거리를 계측하여 운용자에 게 물리적인 경고를 제공하고, 원격지에서 기울기 정보를 전시 하는 모니터링 기능을 포함한 안전 - 운용 시스템을 개발하여 적용하였다. 개발된 이송장치와 안전 - 운용 지원 시스템의 육 상 시운전을 통하여 유용성을 확인하였다.

향후 안전 - 운용 지원 시스템의 하드웨어에 유압을 사용하는 실린더별로 구동 횟수 및 시간에 대한 계측 기능을 추가하고, 유지보수 계획에 반영하기 위한 소프트웨어를 개발하여 이송장 치의 효율적인 운영을 지원할 예정이다. 또한, 실제 마리나 현 장에서 이송장치를 통해 5 톤급 해양레저선박의 상하가 및 운반 에 관한 테스트를 수행할 예정이다.

\section{후 기}

This work was supported by the Technology Innovation Program (20162015, Development of self-leveling transporter for yacht under 20ton) funded By the Ministry of Trade, Industry \& Energy (MOTIE, Korea)

\section{References}

ANSYS Inc., 2018. ASNYS Mechanical User's Guide, 18.0. Baek, S.Y., Park, K.D., Kim, W.I., Cho, S.M., 2011. A Study on Tensile Properties and HAZ Softening Depending on the Amount of Heat Input in MIG Welding of Al6082-T6. Journal of Welding and Joining, 29(1), 59-64. https://doi.org/10.5781/KWJS.2011. 29.1.059

Hong, J.W., Chang, J.I., Yoon, I.J., Lee, J.A., 2015. Study on Socioeconomic Impact of Marine Leisure Industry and Development of Indicators. Korea Maritime Institute, Busan. Hwang, H.G., Yoon, S.W., Kim, T.Y., Kim, B.S., 2017. A Design and Structural Analysis of Automatic Level Control Transporter 
for Leisure Boats under 15 tons. Proceedings of International Conference on Advanced Materials Development and Performance, Pune India, 261. https://doi.org/10.13140/RG.2.2. 11301.60644

Kim, B.S., Hwang, H.G., 2018. A Development of Remote Monitoring and Alarm System for Automatic Position Controlled Boat Transporter. Proceedings of the Korean Society of Marine Engineering, Busan Korea, 231.

Kim, B.S., Hwang, H.G., Shin, I.S., Lee, J.S., Yoo, Y.H., 2016. A Development of Navigation Routes Recommendation System with Elements Analysis of Marine Leisure Activities. Journal of the Korea Institute of Information and Communication Engineering, 20(7), 1355-1362. https://doi.org/10.6109/jkiice. 2016.20.7.1355

Kim, G.Y., Yeo, H.G., Im, J.E., 2018. Marina Facilities Study on Development Plans for the Vitalization of the Marina Industry. Journal of the Korea Academic Society of Tourism and Leisure, 30(1), 279-294.

Marine Travelift, 2019. Products. [Online] Available at: $<$ https:// marinetravelift.com/product/100-bfmii-mobile-boat-hoist/> [Accessed 6 Aug. 2019].

Marina and Marine Industries Association of Korea (MIAK), 2019.
Water-related Leisure Statistics. [Online] Available at: $<\mathrm{http}: / /$ www.marinaportal.kr/rb/?c5/32\&uid4473> [Accessed 6 Aug. 2019].

Ministry of Oceans and Fisheries (MOF), 2018. A Plan for Revitalization of Marine Leisure Tourism.

Moon, J.H., 2018. A Study on the Lift Pier and Equipment of Design Criteria for Effective Vessel Management in the Marina. Journal of the Korean Society of Marine Environment \& Safety, 24(6), 654-661. https://doi.org/10.7837/kosomes.2018.24.6.654

Park, K.D., Han, K.L., Kim, K.S., Park, S.K., 2018. Effects of Perceived Environmental Clues on Fun Factors in Marine Leisure Sports Facilities. The Korea Journal of Sports Science, 27(1), 215-223.

Park, J.W., 2014. A Study on the Standard Model of the Low Carbon Yachting Venue for the 2014 Asian Games. Graduate School Sejong University.

Sea-Lift, 2019. Products. [Online] Available at: $<$ http://www.sea-lift. com/products.cfm $>$ [Accessed 6 Aug. 2019].

SpaceClaim Corporation, 2018. SpaceClaim 2018 Release Notes. Stonimage Technology, 2019. Products. [Online] Available at: $<$ https://www.stonimagecrane.com/boat-hoist/design-and-supp ly-boat-jib-crane-boat-lift-cr.html> [Accessed 6 Aug. 2019]. 